\title{
Society's Books of Note
}

\section{November/December 2015}

Published online: 20 October 2015

(C) Springer Science+Business Media New York 2015

Joseph O. Baker and Buster G. Smith, American Secularism: Cultural Contours of Nonreligious Belief Systems, New York: New York University Press, 2015. \$27.00. 304 pp.

Sociologists Baker and Smith, respectively at East Tennessee State University and Catawba College, document how changes to American society have fueled shifts in the (non)religious landscape and examine the diverse and dynamic world of secular Americans. They offer a framework for understanding nonreligious belief systems as worldviews in their own right, rather than merely as negations of religion.

Maria Jarosz, Bearing Witness: A Personal Perspective on Sixty Years of Polish History. New Brunswick, NJ: Transaction Publishers, 2015. \$39.95. 260 pp.

Maria Jarosz, one of Poland's leading social scientists, combines objective, academic rigor with autobiographical eyewitness accounts of post-World War II Poland and how its people have been affected by changes in politics, power, and society. Zbigniew Brzezinski writes that it is "a remarkable account of unprecedented violence, personal endurance, and finally a recovery of personal as well as national freedom."

David Grazian, American Zoo: A Sociological Safari. Princeton, NJ: Princeton University Press, 2015. \$29.95. 334 pp.

Grazian, associate professor of sociology at the University of Pennsylvania, explores the contemporary zoo with its zookeepers and animal rights activists, parents and toddlers, and all the others that make up the zoo's social world. He shows that in a major shift away from their unfortunate

pasts, American zoos today emphasize naturalistic exhibits, breeding programs for endangered animals, and enrichment activities for their captive creatures.

Michael Javen Fortner, Black Silent Majority: The Rockefeller Drug Laws and the Politics of Punishment. Cambridge, MA: Harvard University Press, 2015. \$29.95. 368 pp.

Often seen as a political sop to the racial fears of white voters, aggressive policing and draconian sentencing for illegal drug possession and related crimes have led to the imprisonment of millions of African Americans-far in excess of their representation in the population as a whole. Michael Javen Fortner, assistant professor and academic director of Urban Studies at CUNY School of Professional Studies, Murphy Institute, shows that these punitive policies were supported by many working-class and middleclass blacks, angry about decline and disorder in their communities.

Paul Maddrell, The Image of the Enemy: Intelligence Analysis of Adversaries since 1945. Washington, DC: Georgetown University Press, 2015. \$32.95. 312 pp.

Maddrell, assistant lecturer in modern history at Loughborough University (UK), drawing on declassified documents and other sources, examines how seven countries analyzed and used intelligence to shape their understanding of their main adversary. The cases in the book include the Soviet Union's analysis of the United States (and vice versa), East Germany's analysis of West Germany (and vice versa), British intelligence on the early years of the "Troubles" in Northern Ireland, Israeli intelligence about the Palestinians, Pakistani intelligence on India, and US intelligence about Islamist terrorists. 